\title{
Insoportable extrañeza
}

Sense 8 |J. Michael Straczynski, Lana Wachowski, Lilly Wachowski |2015

\author{
Micaela Parici
}

Universidad Nacional de Formosa, Argentina

Recibido: 17 de junio 2020; aceptado: 11 de julio 2020

\section{Resumen}

El concepto lacaniano de extimidad permite realizar una lectura de la situación actual de pandemia, con el consecuente confinamiento de los sujetos "aislados socialmente". Es posible pensar en este contexto en relación a nociones como la de segregación y odio al Otro, como agente extraño al que se intenta erradicar, por aquello diferente que nos resulta inquietantemente familiar: su modo de gozar. Se plantea la pregunta de cómo pensar la tolerancia al goce del Otro que se experimenta como insoportable y se busca eliminar. Se toma la serie de Netflix Sense 8 como el escenario que permite enlazar estos conceptos, desde una lógica planteada a modo de ficción de un goce común de los cuerpos.

Palabras clave: Extimidad | pandemia | segregación | odio | cuerpo | goce

Unbearable strangeness

\begin{abstract}
The lacanian concept of extimacy allows to do a reading about the present pandemic situation, with the consequent lockdown of the subjects "socially isolated". It is possible to think about this context in notions like segregation and hate to the Other, like a stranger agent who is tried to eradicate, because of the difference that we find eerily familiar: the way that they enjoy. The question arises of how to think tolerance to the jouissance of the Other, which is experienced as unbearable and seeks to eliminate. The Netflix series Sense 8 is taken as the setting that allows these concepts to be linked, from a logic posed as a fiction of a common enjoyment of bodies.
\end{abstract}

Keywords: Extimacy I segregation I hate I body I jouissance

En su Curso El Otro que no existe y sus comités de ética, J. A. Miller (2005) conceptualiza el racismo en relación al goce del Otro. Eso que se vuelve tan difícil de soportar, que vivimos como ajeno y provoca rechazo, por tocar justamente un punto de lo más propio e íntimo de cada uno; es lo que definimos con la noción de extimidad. De este concepto lacaniano, emparentado a lo "ominoso" (unheimlich) de Freud; podemos decir que indica "lo que está más próximo, lo más interior, sin dejar de ser exterior" algo a lo que Miller (2010) se referirá como la función embaucadora y paradójica de la extimidad, afirmando que es "lo interior de lo más íntimo mío" (p. 53) ¿Cómo pensar la tolerancia al goce del Otro que se experimenta como insoportable? Siendo ese Otro aquí, lo que Miller nombra "Otro sujeto, un lugar" (Miller, 2010, p. 53)

El odio al goce del Otro del que se trata, implica que éste al gozar me sustrae del mío. "Se quiere reconocer en el Otro al prójimo, pero siempre y cuando no sea nuestro vecino. Se lo quiere amar como a uno mismo, pero, sobre todo, cuando está lejos, cuando está separado". (Miller, 2010 , p.53). Pero la raíz de ese odio, no se encuentra en el Otro, sino en el odio al goce propio. Se odia desde un lugar que "no está del todo dentro y no se sabe si está fuera” (Lacan, 2006, p.11).

\section{Pandemia: Extimidad vs. Empatía}

Hago un punto aquí, para tomar un rasgo al que la época nos confronta, en esta lectura del rechazo al goce del Otro y su relación con la extimidad. Por un lado, la pandemia y el confinamiento nos enfrentan a la paranoia generalizada acerca de un virus que no podemos ver, pero que el otro puede contagiarnos; "distanciamiento de los cuerpos" será la consigna que pretenda atemperar ese temor a lo que el Otro representa: un peligro y una

psi_micap@hotmail.com 
amenaza para la propia vida. Por otro lado, el encierro se ha vuelto la solución privilegiada para hacer frente al virus, dejándonos de este modo en una experiencia que Bassols (2020) nombró como "extimidad permanente" (s/p), en relación a la pérdida de libertad y el control de los cuerpos, que deja lo extranjero por fuera de nuestras casas; pero también, del lado de adentro, se trata del encuentro con la diferencia absoluta, con la distancia con uno mismo: lo extrañamente familiar. "El confinamiento no es físico, es más bien subjetivo” ( $\mathrm{s} / \mathrm{p}$ ).

El aislamiento puso en juego la segregación que existía más allá de la pandemia, ubicando al Otro como aquel que puede afectarme, del cual es necesario que me mantenga a distancia. Esto se vio también en el modo en que este virus fue nombrado, primero como "el virus de los ricos", viéndose afectados aquellos que se encontraban en un lugar distinto al del origen, "extranjero" y lo traían desde afuera; para luego pasar a ser "el virus de los pobres", aumentando las muertes en zonas de mayor precariedad y con menores posibilidades en materia de salud. Entonces, una diferencia entre el Otro de afuera y el que se encuentra protegido adentro, acompañó el modo en que se fue instalando esta situación mundial. Al decir de Pierre- Guilles Gueguen "vivimos en una sociedad de exclusión (...) nunca ha habido tanta segregación. Nunca lo simbólico y lo imaginario han sido tan desarrollados, y jamás habíamos visto tanto desencadenamiento de violencia" (Gueguen, 1998, p. 13).

Del otro lado, desde otros discursos, la pandemia se presenta como un momento de supuesto "cambio en la subjetividad", en el que se pone en juego un llamado a la "empatía" como recurso a través del cual surja una especie de transitivismo sobre lo que el Otro experimenta; desde el psicoanálisis, este se vuelve un concepto paradójico ya que se trataría de "ponerse en el lugar del Otro", a sabiendas de que toda lectura del otro siempre será fantasmática. Sobre eso Lacan, tomando el axioma religioso "amarás a tu prójimo como a ti mismo", nos dice

la naturaleza del bien es ser altruista. Pero éste no es el amor al prójimo (...) cada vez que Freud se detiene, como horrorizado, ante la consecuencia del mandamiento del amor al prójimo, lo que surge es la presencia de esa maldad fundamental que habita en ese prójimo. Pero, por lo tanto, habita también en mí mismo. ¿Y qué me es más próximo ${ }^{1}$ que ese prójimo, que ese núcleo de mí mismo que es el del goce, al que no oso aproximarme? Pues una vez que me aproximo a él- este es el sentido de El malestar en la cultura- surge esa insondable agresividad ante la que retrocedo, que vuelvo en contra mío. (Lacan, 1960, p.225).

\section{Odio hétero}

Indistintamente del sexo, decimos que el inconsciente es hétero. Esto puede interpretarse desde esa relación al goce femenino que insiste más allá de la lógica del falo. Hay una alteridad irreductible del goce, que Lacan nombra como Otro Goce, del que nada se quiere saber y que se rechaza "con la segregación y la violencia" para extirparlo, “es ese 'no quiero saber nada de eso' que insiste en cada ser hablante y en las diversas formas de segregación que existen en nuestro mundo" (Bassols, 2018, p.87). Odiamos ese goce, por no reconocerlo propio. Freud (1976) nombrará así, esta experiencia: "He de experimentar entonces que esto negado por mí, no sólo está en mi sino que también actúa ocasionalmente desde mi interior" (p.2894).

Lo que se presenta entonces como diferente, en relación al goce, puede experimentarse desde el odio más radical, ¿es la intolerancia al goce del Otro o el odio a lo hétero del goce propio lo que se pone en juego? Es allí donde pueden situarse las diversas formas en que se intenta eliminar eso diferente, que al mismo tiempo se encuentra en el corazón mismo del goce del sujeto.

La serie Sense 8 (Netflix, 2015 - 2018) plantea el lazo que se establece entre 8 sujetos cuyos cuerpos se encuentran en diversos países alrededor del mundo, pero cuya condición de sense los conecta... ¿desde el afecto? ¿el pensamiento? ¿el cuerpo? O todas ellas... hay una sensación que traspasa los límites físicos y acerca los cuerpos, logrando de esa manera que les sea posible resolver diversas situaciones. Durante los distintos capítulos intentan salvarse de un científico que quiere extirparles esa especie de "don”, exterminándolos, y se puede interpretar, tal como en las distintas versiones de la Saga de Los X Mens, que todo aquello que evidencie una diferencia con la raza humana debe ser erradicado.

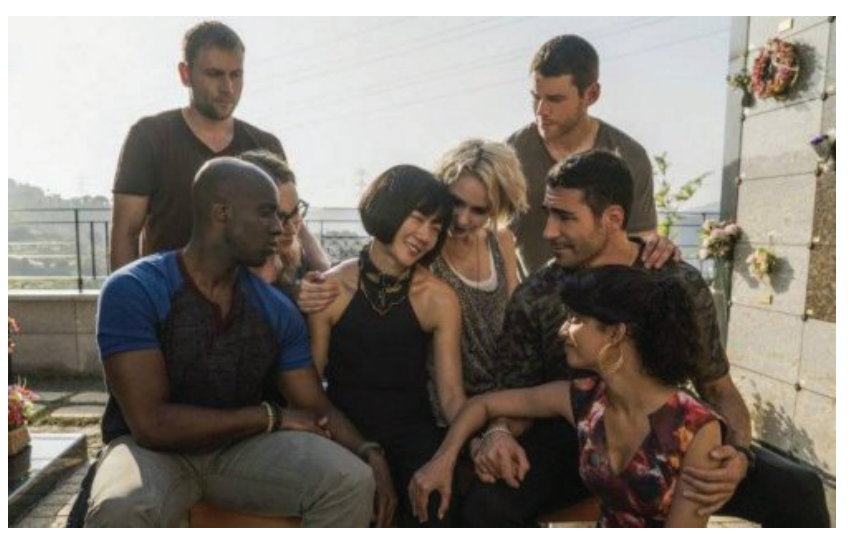


Aparece un elemento que podría situarse en esta misma línea de lectura, que es el hecho de que esos cuerpos que se pretende controlar y eliminar, se enlazan desde un goce sexual aparentemente compartido, goce que trasciende fronteras y géneros, en escenas en que los cuerpos se transforman en uno. Por su condición de senses (que significa estar mental y emocionalmente conectados) pueden ver y sentir lo mismo, siendo un rasgo que se destaca en la serie, el hecho de que cada uno de ellos es de una raza, cultura, etnia, sexuación; distinta. De algún modo podría decirse que borran la diferencia, haciendo existir lo que Eric Laurent (2019) refiere como una de las características del cuerpo hablante, cuando afirma "es un cuerpo que hace vínculo con los otros cuerpos, más allá de las identificaciones, mediante una experiencia de goce común” (p.49).

Pienso la serie a partir de los conceptos anteriormente tomados: una conexión de lo más íntima sucede entre sujetos que se consideran extraños, que experimentan un goce "común", lo que el Otro de la ciencia rechaza y pretende erradicar, por su condición de diferente: odio al goce del Otro. En esta serie las categorías están borradas, hay un goce sexual que implica a todos, en el que no hay una restricción de lo hétero u homo. Ese es, interpreto, el detalle de la serie en relación a lo éxtimo del goce. Eso que se experimenta como inquietante extrañeza y que para estos personajes, desde la ficción, pareciera ser una diferencia inexistente.

Si decimos entonces que es esa extranjeridad que inquieta lo que empuja a la ciencia al exterminio de la diferencia, como vemos en la serie ¿cómo pensar un paralelismo posible con el contexto actual? Si bien, cabe distinguir que es una ficción a la que se hace aquí referencia, y que no se podría hablar de "eliminar" al extraño; el Otro se constituye como el representante del contagio, de aquello que pone en riesgo la propia vida... no se trata de la diferencia en su modo de gozar, sino del virus que aloja o no en su cuerpo.

De este modo, todos aislados, todos segregados, todo cuerpo siendo objeto de sospecha y control bajo políticas públicas sanitaristas "de protección" y vigilancia... la noción de extranjero cobra hoy valor de verdad.

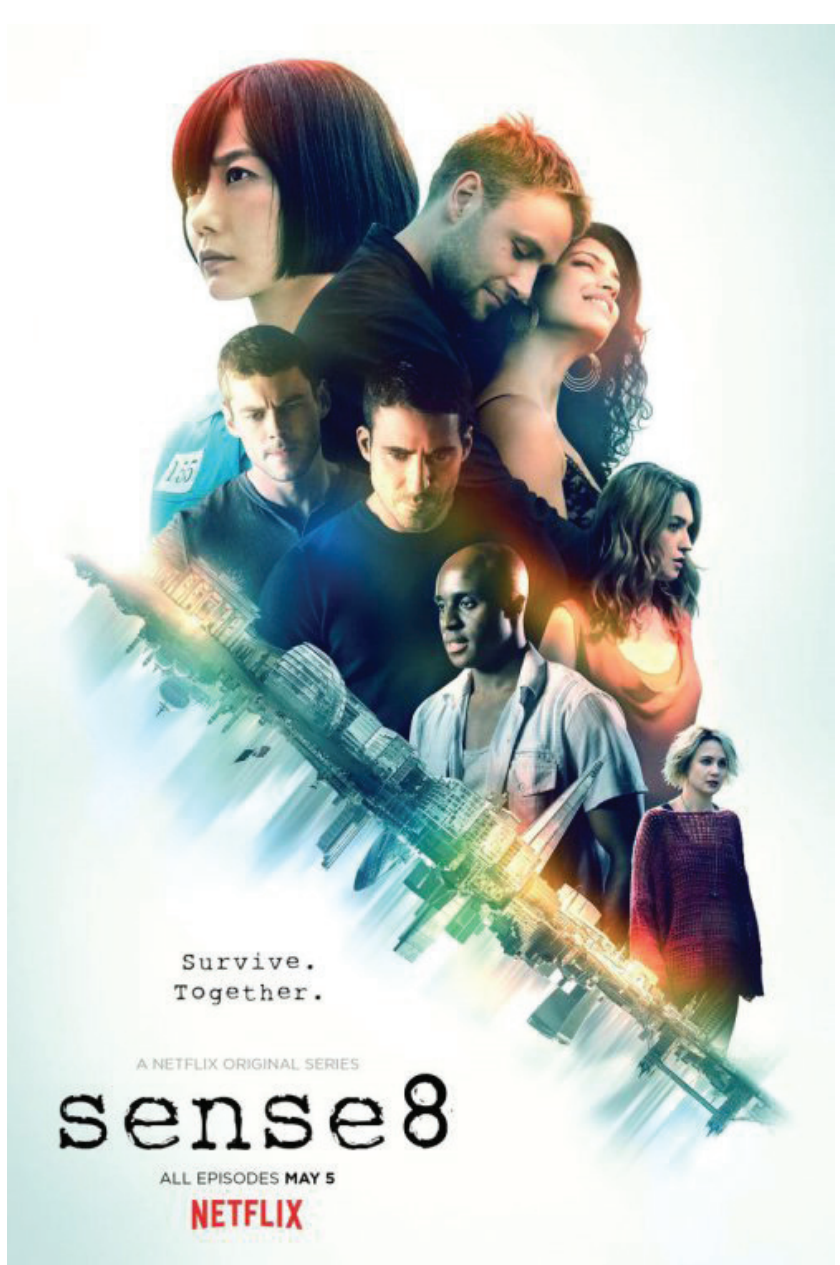

\section{Referencias}

Bassols, M. (2018). El goce es queer por definición. En Feminismos, variaciones y controversias. Colección Orientación Lacaniana. Buenos Aires: Grama.

Bassols, M. (2020). Distanciamiento Social y acercamiento subjetivo. Ciclo de Conferencias: Pulsos de nuestra época. Antena Clínica de Valencia. Recuperado de: http://www.scf-valencia.es/video-miquel-bassols-distanciamiento-social-y-acercamiento-subjetivo/

Freud, S. (1999). La responsabilidad moral por el contenido de los sueños. En Obras Completas. Tomo III. Buenos Aires: Amorrortu.

Gueguen, P.- G. (1998). Formas contemporáneas del Malestar en la Cultura. Revista Registros. Año 6. Tomo Metal. Buenos Aires: Escuela de la Orientación Lacaniana.

Lacan, J. (1964). Los cuatro conceptos fundamentales del Psicoanálisis. El Seminario de Jacques Lacan. Libro XI. Buenos Aires: Paidós.

Lacan, J. (1960). La ética del psicoanálisis. El Seminario de Jacques Lacan. Libro VII. Buenos Aires: Paidós.

Laurent, E. (2019). Lógica del cuerpo hablante en la civilización. En Creencias. Buenos Aires: Grama. 
Miller, J. -A. (2010). Extimidad. Los cursos psicoanalíticos de Jacques-Allain Miller. Buenos Aires: Paidós.

Miller, J.- A. (2005). El Otro que no existe y sus comités de ética. Los cursos psicoanalíticos de Jacques-Allain Miller. Buenos Aires: Paidós.

Wachowski, L., Wachowski, L., Straczynski, J-M., Hill, G., Holland, C., Friedlander, P., Duncan, T. (productores) y Wachowski, L., Wachowski, L., y Straczynski, J-M. (creadores). (2015-2018). Sense 8 [serie televisiva]. Estados Unidos: Netflix.

1 Prochain, en francés, es a la vez próximo y prójimo. 